\title{
Comparison of methods for determining the color of Chilean honeys and the relationship of color with botanical origin in central Chile
}

\author{
María José Martin ${ }^{1,3}$, Carolina Fredes ${ }^{2}$, Gabriel Nuñez ${ }^{2}$, Rosanna \\ Ginocchio $^{1,3}$, and Gloria Montenegro ${ }^{2}$ \\ ${ }^{1}$ Departamento de Ecosistemas y Medioambiente, ${ }^{2}$ Departamento de Ciencias Vegetales, Facultad de \\ Agronomía e Ingeniería Forestal, ${ }^{3}$ Centro de Ecología Aplicada y Sustentabilidad, Pontificia Universidad \\ Católica de Chile. Casilla 306-22, Santiago, Chile.
}

\begin{abstract}
M.J. Martin, C. Fredes, G. Nuñez, R. Ginocchio, and G. Montenegro. 2014. Comparison of methods for determining the color of Chilean honeys and the relationship of color with botanical origin in central Chile. Cien. Inv. Agr. 41(3): 411-418. The color of honey has special relevance in the international market, as different markets demand specific colors of honey. Chile has very diverse native and exotic flora, which are used by bees (Apis mellifera) to produce a range of honey types, including honeys of different colors. In this context, determining the relationships between color and botanical origin among Chilean honeys is very relevant. The objectives of the present study were to compare three methodologies for determining color in Chilean honeys (Pantone ${ }^{\circledR}$, optical density (OD), and Pfund) and to define the relationship between color and botanical origin of the characterized honeys. The most common honeys from the Libertador Bernardo O'Higgins Region (VI Region) of Chile were Galega officinalis, Quillaja saponaria, and Retanilla trinervia unifloral honeys, all of which have lighter colors than internationally described. Both the OD and Pfund methods could identify significant differences between dominant species; specifically, these methods were able to discriminate between G. officinalis and Q. saponaria honeys and between G. officinalis and R. trinervia honeys. The OD and Pfund methods revealed that honeys of G. officinalis (A530 nm: 0.93 and $95.53 \mathrm{~mm}$ Pfund) were darker than those of Q. saponaria (A530 nm: 0.42 and $80.66 \mathrm{~mm}$ Pfund) and R. trinervia (A530 nm: 0.35 and $73.41 \mathrm{~mm}$ Pfund). Although the three methods for determining the color of Chilean honeys had different efficacies, the OD method was able to discriminate among dominant species and honey types. Significant correlations among the dominant species were found for Chilean honeys from the Libertador Bernardo O'Higgins Region using both the OD and Pfund methods.
\end{abstract}

Key words: Honey markets, melissopalynological analysis, optical density, Pantone ${ }^{\circledR}$, Pfund.

\section{Introduction}

Honey is a natural sweet substance that is produced by honeybees (Apis mellifera Linnaeus)

Received February 25, 2014. Accepted October 28, 2014. Corresponding author: cpfredes@uc.cl from the nectar of flowers, secretions of living plant parts and/or excretions of plant-sucking insects that bees collect and transform by combining with specific substances. The substances are finally deposited, dehydrated, and stored in honeycombs until they mature (FAO, 1981). Sugars and water are the main chemical components 
of honey ( $>95 \%)$, and fructose (38\%) and glucose $(31 \%)$ are the main constituents. Proteins, aromatic aldehydes, aromatic carboxylic acids and esters, carotenoids, terpenoids, and phenolic compounds are also components of natural honey and contribute to its flavor (Muñoz et al., 2007). Honey composition varies and depends on regional and climatic conditions as well as the type of flowers visited by bees (Fredes and Montenegro, 2006; Muñoz et al., 2007). The quality of honey is mainly determined by its chemical, sensory, physical and microbiological characteristics (Alvarez -Suarez et al., 2010; Alqarni et al., 2012; Sant'Ana et al., 2014).

The color of honey has special relevance in the international market, as it is an indicator of flavor intensity. Honey is commercialized according to its color, and different markets demand specific colors. For example, clear honeys (water white, extra white, and white) with less intense flavor are preferred in the U.S. market, whereas darker honeys (extra light amber, light amber, amber, and dark amber) with a strong flavor are preferred in the European market (Delmoro et al., 2010). Therefore, the availability of reliable and internationally accepted methods for the determination of honey color is important for supporting the market decision-making process of honey exporters (Delmoro et al., 2010).

Methods of honey color analysis range from minimal treatment and heavy reliance on human sensory perception to relatively intensive treatment and no human sensory perception (Delmoro et al., 2010). Strict sensory measurement is the basis of the Pantone ${ }^{\circledR}$ method. On the other extreme, the optical density (OD) method is entirely reliant upon instrumental analysis (Alqarni et al., 2012). However, this method has not been standardized or implemented for honeys in a practical way. As an intermediate between the Pantone ${ }^{\circledR}$ and OD methods, the Pfund method is based on the application of instrumental visual comparison of a honey sample against a standard.
The main factors that affect the color of honeys are the botanical origin and composition of nectar, honey processing techniques, temperature, and storage time (Delmoro et al., 2010; Alqarni et al., 2012; Sant'Ana et al., 2014). In Chile, highly diverse native and exotic flora have been used by honeybees for honey production (Fredes and Montenegro, 2006). Therefore, a range of honey types with different botanical origins, chemical compositions, and color variations is thus expected. Honey color has been studied previously (Díez et al., 2004; Alvarez -Suarez et al., 2010; Delmoro et al., 2010; Alqarni et al., 2012; Moniruzzaman et al., 2013; Sant'Ana et al., 2014). Díez et al. (2004) studied the color of 152 honeydew honeys from Morocco using an instrumental method and found that the color varies naturally, ranging from light yellow to amber, dark amber and black in extreme cases; occasionally, even green and red hues can be observed. There is not much information available regarding the color of Chilean honeys and the possible correlation between color and botanical origin. However, such information is very relevant for Chilean honey exporters. The objectives of the present study were to compare three methodologies that are used internationally for determining color in Chilean honeys (Pantone ${ }^{\circledR}, \mathrm{OD}$, and Pfund) and to define the relationship between the color and botanical origin of these characterized honeys.

\section{Materials and methods}

\section{Honey samples and pollen analysis}

A total of 91 honey samples (Figure 1) were collected from beekeepers in central Chile (Libertador Bernardo O’Higgins Region) during the harvest season (November 2012 to August 2013). These honey samples were processed by centrifugation and stored at room temperature until analysis. Information about the dominant flora present in all sampling sites was also recorded. 


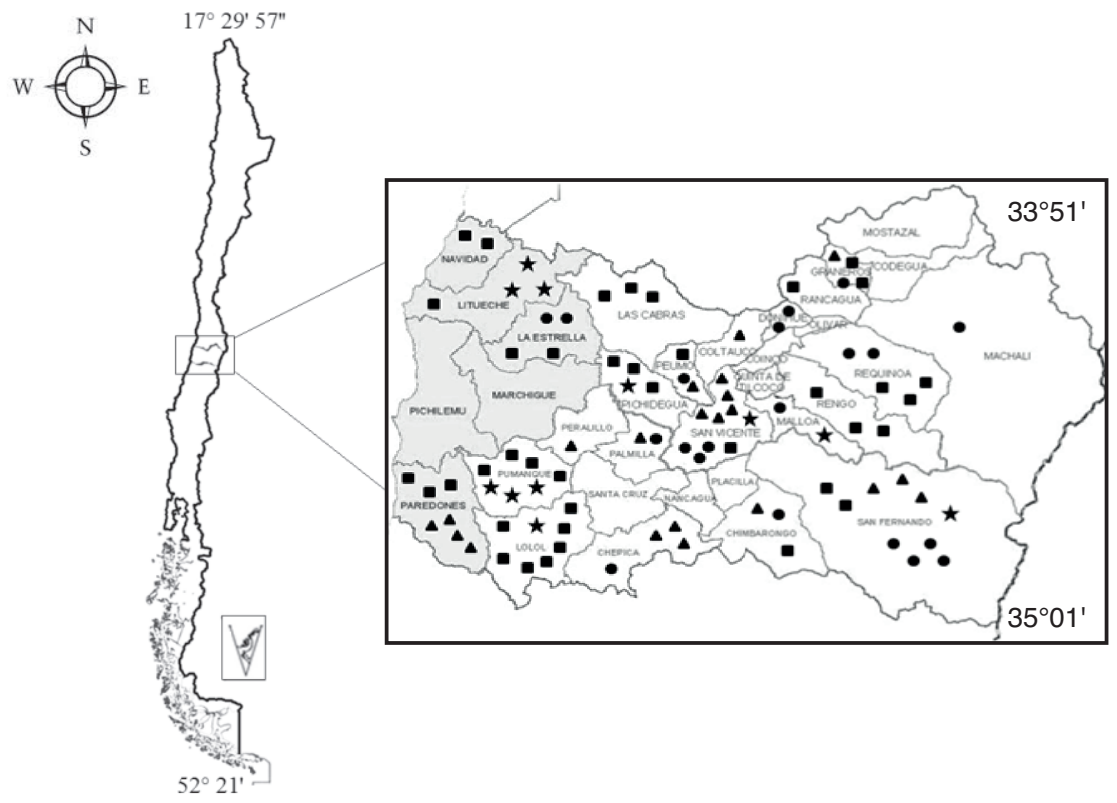

Figure 1. Map of the Libertador Bernardo O'Higgins Region (VI Region) in central Chile and the origins of the 91 studied honey samples based on the local municipal boundaries. $\Delta$ G. officinalis honeys $(\mathrm{n}=21), \bullet Q$. saponaria honeys $(\mathrm{n}=20), \star R$. trinervia honeys $(\mathrm{n}=11)$, and - honeys with other botanical origins ( $\mathrm{n}=39)$.

All honey samples were characterized by melissopalynological analysis to certify the botanical origin as described in Chilean Regulation $(\mathrm{NCH})$ 2981 of 2005 (Montenegro et al., 2008). Identified pollen grains were compared using a pollen grain library (Heusser, 1971; Sawyer, 1981; Montenegro, 2012). The data analysis was conducted using statistical analysis of proportions, and maximum likelihood estimation was used to construct confidence intervals. The identified pollen grains were classified into four classes according to their frequency: dominant ( $>45 \%)$, secondary (15-45\%), important minor (3-15\%), and trace $(<3 \%)$ (Louveaux et al., 1978). For the determination of frequency classes, 1,000 pollen grains were counted.

\section{Determination of honey color}

Fifty-two samples (500 g) of the most common honeys (Galega officinalis Linnaeu, Quillaja saponaria Molina, and Retanilla trinervia [Gillies \& Hook.] Hook. \& Arn.) from the Liberta- dor Bernardo O’Higgins Region were carefully homogenized by hand. Three 10 -g aliquots of each honey sample were then heated to $45-50$ ${ }^{\circ} \mathrm{C}$ to dissolve the sugar crystals before applying each methodological procedure (Pantone ${ }^{\circledR}, \mathrm{OD}$, and Pfund).

For Pantone ${ }^{\circledR}$ analysis, the aliquots were compared by eye to a color guide (Pantone ${ }^{\circledR}$, Plus Series Formula Guide, solid uncoated) under white light. A specific color code was recorded for each honey sample. OD measurements were performed following the method described by Alqarni et al. (2012). Briefly, 1-g aliquots of honey were diluted with $9 \mathrm{~mL}$ of distilled water and centrifuged at $3,000 \mathrm{rpm}$ for $10 \mathrm{~min}$. The absorbance of the filtrate supernatant was measured at $530 \mathrm{~nm}($ A530 $\mathrm{nm})$ against distilled water as blank using a computerized UV-VIS spectrophotometer (Shimadzu UV-1700 Pharma Spec). For Pfund color analysis, $5 \mathrm{~mm}$ cuvettes were filled with homogenous liquid honey, and care was taken to prevent air bubbles from entering the honey samples. Each aliquot was 
then measured with a honey color photometer (Hanna HI 96785, Hanna Instruments, USA) and compared to analytical grade glycerol, which served as a standard reference (Moniruzzaman et al., 2013). Color was expressed as mm Pfund according to the Pfund classifier. The measurements were performed in triplicate for each methodological procedure.

\section{Statistical analysis of the determination of botanical origin using honey color}

Honey color data obtained via the OD and Pfund procedures were analyzed using twoway general linear model ANOVAs. The main factors considered were dominant species $(G$. officinalis, $Q$. saponaria, and $R$. trinervia) and honey type (unifloral and multifloral). Pearson simple and partial correlations between botanical origin and methodological procedure were also calculated $(\mathrm{P} \leq 0.05)$. All statistical analyses were performed with SAS 9.2 software for Microsoft Windows (SAS Institute Inc., Cary, NC, 2009).

\section{Results and discussion}

\section{Pollen analysis and botanical origin}

Honey samples $(\mathrm{N}=91)$ from the same geographical region and harvest season were melissopalynologically analyzed, as botanical origin is one of the main factors that affects the color of honey (Alqarni et al., 2012; Moniruzzaman et al., 2013). A total of 33 different pollen grain types were found in the honey samples. Three main unifloral honeys (pollen frequency $>45 \%$ ) belonging to a single plant species according to Montenegro et al. (2008) could be described for the study samples: G. officinalis (14 samples), Q. saponaria (18 samples), and $R$. trinervia (7 samples) (Table 1). Multifloral honeys (pollen frequencies in the range of $15-45 \%$ ) were also identified by melissopalynological analysis, with G. officinalis (7 samples), Q. saponaria (2 samples), and $R$. trinervia (4 samples) again being the most common. Annual species such as Medicago sativa and Trifolium repens had secondary and minor importance (3-15\%) in most analyzed multifloral honeys. This result can be explained by fact that these high nectar-producing annual species share the same flowering period with $Q$. saponaria and $R$. trinervia, two dominant woody native species in the study area (Montenegro et al., 2008).

Table 1. Main pollen (\%) types in 52 honeys from the Libertador Bernardo O’Higgins Region in central Chile.

\begin{tabular}{|c|c|c|c|}
\hline $\begin{array}{l}\text { Pollen Class } \\
\text { Honey Type }\end{array}$ & Dominant & Secondary & Important Minor \\
\hline Unifloral $(n=14)$ & 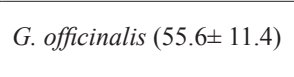 & - & $\begin{array}{l}\text { Q. saponaria }(14.5 \pm 10.8), \text { M. sativa }(7.9 \pm \\
\text { 3.2), Brassica } \text { sp. }(6.9 \pm 7.1)\end{array}$ \\
\hline Multifloral $(\mathrm{n}=7)$ & & 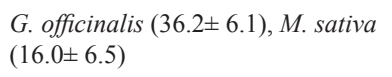 & $\begin{array}{l}\text { T. repens }(7.4 \pm 5.1), \text { Q. saponaria }(19.8 \pm \\
9.4)\end{array}$ \\
\hline Unifloral ( $\mathrm{n}=18)$ & Q. saponaria $(57.8 \pm 12.6)$ & G. officinalis $(20.1 \pm 8.6)$ & M. sativa $(7.60 \pm 5.6)$, T. repens $(4.8 \pm 2.5)$ \\
\hline Multifloral $(\mathrm{n}=2)$ & & Q. saponaria $(37.9 \pm 3.6)$ & $\begin{array}{l}\text { M. sativa }(14.3 \pm 11.4), \text { G. officinalis } \\
(15.0 \pm 8.8), \text { T. repens }(9.3 \pm 1.1)\end{array}$ \\
\hline Unifloral $(\mathrm{n}=7)$ & R. trinervia $(57.8 \pm 10.4)$ & - & $\begin{array}{l}\text { S. humboldtiana }(11 \pm 10.8), T \text {. } \\
\text { quinquenervia }(8.0 \pm 2.8), \text { Brassica } \mathrm{sp} \text {. } \\
(7.4 \pm 3.7)\end{array}$ \\
\hline Multifloral ( $\mathrm{n}=4)$ & & R. trinervia $(34.3 \pm 2.6)$ & $\begin{array}{l}\text { M. sativa }(10.6 \pm 7.9), \text { G. officinalis }(10.2 \pm \\
\text { 3.6), Brassica } \mathrm{sp} .(8.0 \pm 4.3)\end{array}$ \\
\hline
\end{tabular}

The results are expressed as the mean \pm standard deviation. Pollen was classified into dominant $(>45 \%)$, secondary (15$45 \%$ ), and important minor (3-15\%) classes according to frequency. 


\section{Color of the honey samples}

According to the Pantone ${ }^{\circledR}$ method, the Chilean honeys analyzed in this study have a color range between $110 \mathrm{U}$ and $7550 \mathrm{U}$. Because this method delivers individual color codes for each analyzed sample, only qualitative frequency characterizations were performed (Figure 2). The Pantone method provides a wide range of color resolution; therefore, it is difficult to assign a specific color to a particular honey based on visual perception (Delmoro et al., 2010). This was reflected in the results, as the Pantone ${ }^{\circledR}$ method was not able to discriminate the colors of honey by dominant species and honey type. According to our results, although the Pantone ${ }^{\circledR}$ method was easy and inexpensive to perform, this method would not allow for discriminating among honeys of different botanical origins (Pantone ${ }^{\circledR}$ code is not quantitative data).
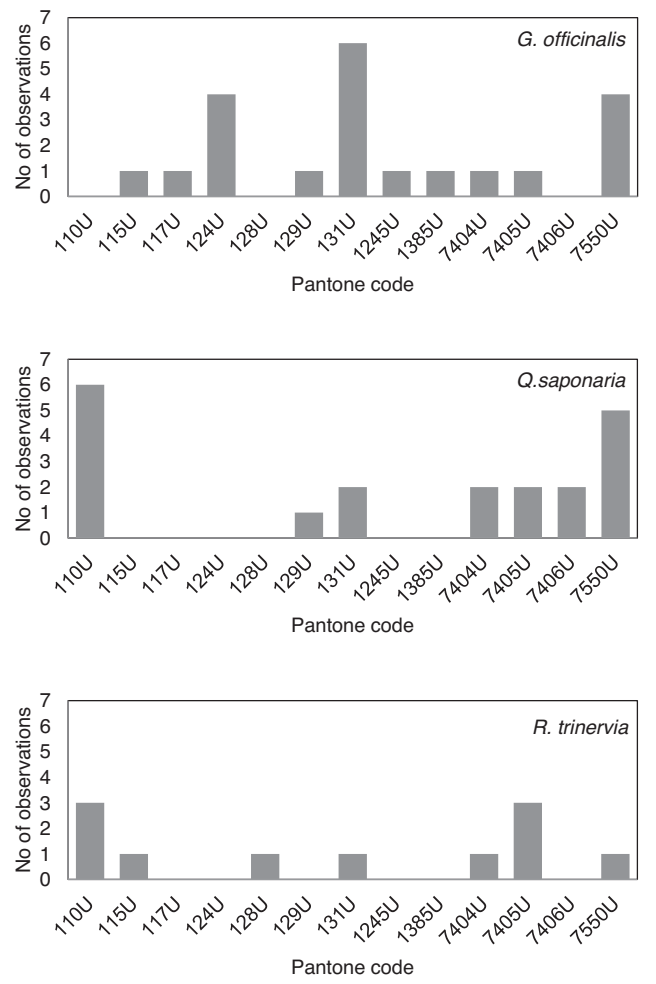

Figure 2. Histograms of G. officinalis, Q. saponaria, and $R$. trinervia honey colors determined with the Pantone ${ }^{\circledR}$ method.
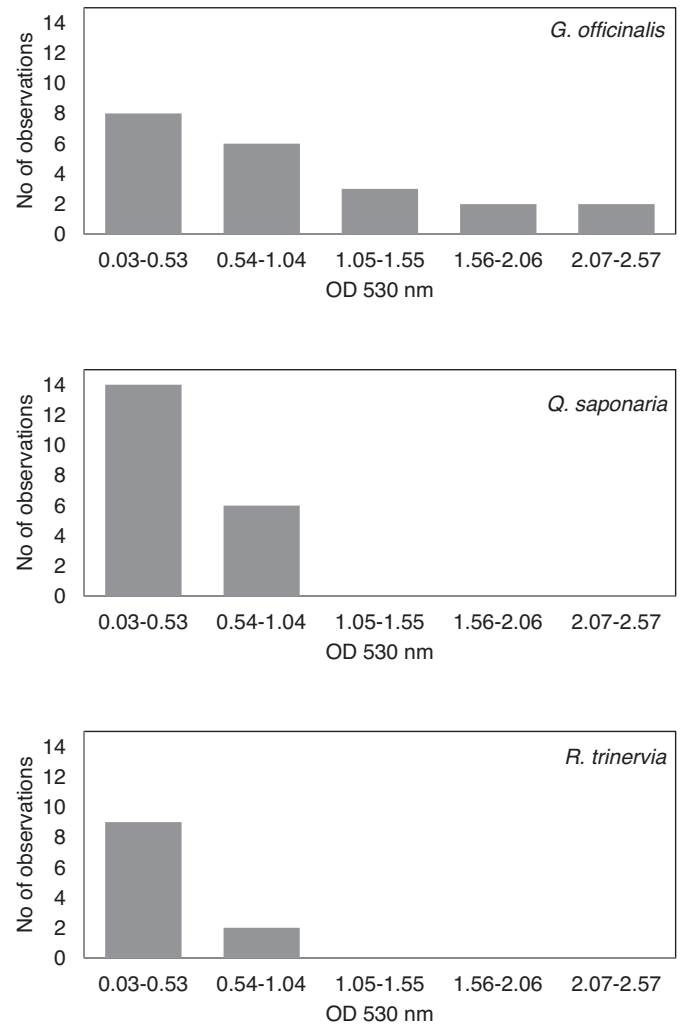

Figure 3. Histograms of G. officinalis, $Q$. saponaria, and $R$. trinervia honey colors determined with the optical density (OD) method.

In contrast, the OD method (Figure 3) showed that the honeys had a color range of A530 nm: $0.03-2.41$. These results indicate that the studied Chilean honeys were lighter in color than Saudi honeys (A530 nm: 0.50-7.25) (Alqarni et al., 2012). Additionally, the OD method was the most time-consuming method due to the many steps required for preparing the samples.

The Pfund method (Figure 4) indicated a range between extra light amber to dark amber (50.0$128.7 \mathrm{~mm}$ Pfund) according to the United States Department of Agriculture (USDA) color standard designations. The studied Chilean honeys were lighter than Malaysian honeys, which exhibit a dark amber (150 mm Pfund) color (Moniruzzaman et al., 2013). Sant'Ana et al. (2014) described that Brazilian honeys exhibited a color range from light amber to amber (77.3-105.9 mm Pfund). Our results indicate that Chilean honeys have a wider 

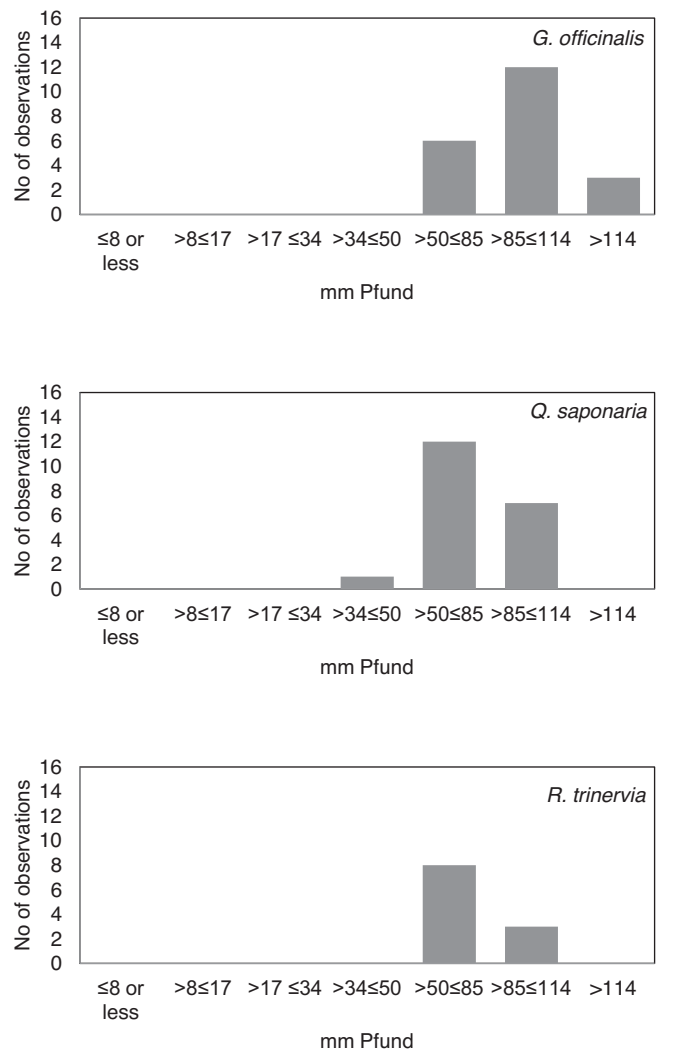

Figure 4. Histograms of G. officinalis, Q. saponaria, and $R$. trinervia honey colors determined with the Pfund method.

color range than Brazilian honeys, as extra light amber-colored honey was found among the Chilean honey samples but not among the Brazilian samples.

ANOVA of the OD method showed that dominant species $(\mathrm{F}=28.27, \mathrm{P} \leq 0.05)$, honey type $(\mathrm{F}=16.56$, $\mathrm{P} \leq 0.05)$, and the interaction factor $(\mathrm{F}=4.03, \mathrm{P} \leq 0.05)$ had significant effects. The OD method was able to discriminate the colors of honeys derived from different dominant species; specifically, this method could discriminate between $G$. officinalis and $Q$. saponaria honeys and between $G$. officinalis and $R$. trinervia honeys. The OD method was also able to discriminate between the colors of unifloral and multifloral honeys of the same dominant species, specifically for the G. officinalis honeys. Honeys of G. officinalis (A530 nm: 0.93) were in fact darker than those of Q. saponaria (A530 nm: 0.42) and $R$. trinervia (A530 nm: 0.35) (Figure 3). Nevertheless, some honeys of G. officinalis, Q. saponaria and R. trinervia showed similar OD values (A530 $\mathrm{nm}$ : 0.03-1.04) in the lowest values of the color range. The results obtained with the Pfund method showed that the dominant species had a significant effect $(\mathrm{F}=$ 26.42, $\mathrm{P} \leq 0.05)$, but honey type $(\mathrm{F}=0.07, \mathrm{P}=0.79)$, and the interaction factor $(\mathrm{F}=2.96, \mathrm{P}=0.054) \mathrm{did}$ not. This indicates that the Pfund method is sensitive enough to discriminate the color of honey collected or processed from dominant species; specifically, it can discriminate between $G$. officinalis and $Q$. saponaria honeys and between $G$. officinalis and $R$. trinervia honeys. The Pfund method was not able to discriminate different honey types from the same dominant species (unifloral or multifloral honeys). This indicates that the OD method is more sensitive than the Pfund method due to its ability to discriminate between dominant species and honey types. Honeys from G. officinalis (95.53 $\mathrm{mm}$ Pfund) were darker in color than those from Q. saponaria (80.66 mm Pfund) and $R$. trinervia (73.41 mm Pfund) (Figure 4).

Pfund is the most common method used for the determination of honey color because it is an easy, quick, and reproducible method (Delmoro et al., 2010; Moniruzzaman et al., 2013; Sant'Ana et al., 2014). According to our analytical experience, the OD method is more susceptible to the measurement conditions (time of sample exposure and presence of pollen in the honey) than the Pfund method. Therefore, the OD method can be recommended for certain types of studies in which a high level of discrimination is sought. Nevertheless, minimal information about the application of this method in honey is available (Alqarni et al., 2012).

\section{Correlation between color and botanical origin of Chilean honeys}

Significant correlations between the dominant species and both OD $(r=-0.47, \mathrm{P} \leq 0.0001)$ and Pfund ( $r=-0.49, P \leq 0.0001)$ methods were found. Honey type did not show a significant correlation with any of the methods. These results are 
concordant with the ANOVA results indicating that OD and Pfund methods can be used to discriminate honeys from different dominant species when the honey color is different.

In summary, the three methods for determining the color of Chilean honeys had different efficacies. Although the Pfund method is easier, quicker and more reproducible than the OD method, the latter method was able to discriminate among dominant species and among honey types. Therefore, the OD method has the highest level of discrimination among the three studied methods.

The results of this study allow the classification of G. officinalis, $Q$. saponaria, and $R$. trinervia honeys based on their colors by applying OD and Pfund methods. These methods can serve as complementary tools to melissopalynological analysis. Further studies of honeys with other botanical and geographic origins should be performed to validate these methods.

\section{Acknowledgements}

The authors are grateful for financial support from Chilean Public Institutions: The National Fund for Scientific and Technological Development (FONDECYT Grant 1110808) and The National Commission for Scientific and Technological Research (CONICYT FB 0002 (2014)).

\title{
Resumen
}

\begin{abstract}
M.J. Martin, C. Fredes, G. Nuñez, R. Ginocchio y G. Montenegro. 2014. Comparación de métodos para determinación de color en mieles chilenas y su relación con el origen botánico. Cien. Inv. Agr. 41(3):411-418. El color de la miel tiene especial relevancia en el mercado internacional, debido a que diferentes mercados demandan diferentes colores de miel. Chile presenta una gran diversidad de especies nativas e introducidas que son utilizadas por las abejas (Apis mellifera) para la producción de miel. Por lo tanto, se esperaría encontrar mieles en una gran diversidad de colores. En este contexto, es muy relevante la determinación de relaciones entre el color y el origen botánico de las mieles chilenas. Los objetivos de esta investigación fueron comparar tres metodologías para la determinación de color en mieles chilenas (Pantone ${ }^{\circledR}$, densidad óptica [DO] y Pfund), junto con definir la relación entre el color y el origen botánico. Las mieles más comunes de la Región del Libertador Bernardo O〉Higgins (VI Región) de Chile fueron de Galega officinalis, Quillaja saponaria y Retanilla trinervia, con colores más claros que los descritos internacionalmente para otras mieles. Tanto el método de DO como el método Pfund mostraron un efecto significativo para las especies dominantes, siendo estos métodos capaces de discriminar entre mieles de G. officinalis y $Q$. saponaria y entre mieles de G. officinalis y R. trinervia. Mieles de G. officinalis (A530 nm: 0,93 y 95,53 mm Pfund) fueron más oscuras que las de $Q$. saponaria (A530 nm: 0,42 y 80,66 mm Pfund) y R. trinervia (A530 nm: 0,35 y 73,41 mm Pfund) cuando se utilizó el método de DO y Pfund, respectivamente. Aunque los tres métodos para la determinación del color de mieles chilenas presentaron eficacias diferentes, el método de DO fue capaz de discriminar tanto entre las especies dominantes y tipo de miel. Se encontraron correlaciones significativas entre las especies dominantes tanto para el método de DO como para el método Pfund para mieles chilenas de la Región Libertador Bernardo O’Higgins.
\end{abstract}

Palabras clave: Análisis melisopalinológico, densidad óptica, mercados de miel, Pantone, Pfund. 


\section{References}

Alqarni, A.S., A.A. Owayss, A.A. Mahmoud, and M.A. Hannan. 2012. Mineral content and physical properties of local and imported honeys in Saudi Arabia. Journal of Saudi Chemical Society. doi: 10.1016/j.jscs.2012.11.009.

Alvarez-Suarez, J., S. Tulipani, D. Díaz, Y. Estevez, S. Romandini, and F. Giampieri. 2010. Antioxidant and antimicrobial capacity of several monofloral cuban honeys and their correlation with color, polyphenol content and other chemical compounds. Food and Chemical Toxicology 48(8-9): 2490-2499.

FAO, 1981. Codex Standard for Honey Codex Stan 12-1981, Revised 1 (1987), Revised 2 (2001), p.1-8.

Delmoro, J., D. Muñoz, V. Nadal, A. Clementz, and V. Pranzetti. 2010. El color en los alimentos: determinación de color en mieles. Invenio 13 (25): 145-152.

Díez, M.J., C. Andrés, and A. Terrab. 2004. Physicochemical parameters and pollen analysis of Moroccan honeydew honeys. International Journal of Food Science and Technology 39: 67-176.

Fredes, C., and G. Montenegro. 2006. Heavy metals and other trace elements contents in Chilean honey. Ciencia e Investigación Agraria 33: 48-55.

Heusser, C.J. 1971. Pollen and Spores of Chile. University of Arizona Press, Tucson, Arizona, USA, $167 \mathrm{pp}$.
Louveaux, J., Maurizio A, and Vorwohl G. 1978. Methods of Melissopalynology, Bee World 59: 139- 157.

Moniruzzaman, M., S.A. Sulaiman, M.I. Khalil, and S.H. Gan. 2013. Evaluation of physicochemical and antioxidant properties of sourwood and other Malaysian honeys: a comparison with manuka honey. Chemistry Central Journal 7: 138-150.

Montenegro, G. 2012. Polen Apícola Chileno: Diferenciación y usos según sus propiedades y origen floral. Ediciones Pontificia Universidad Católica de Chile. Santiago, Chile. 161 pp.

Montenegro, G., M. Gómez, J. Díaz-Forestier, and R. Pizarro. 2008. Aplicación de la Norma Chilena Oficial de denominación de origen botánico de la miel para la caracterización de la producción apícola. Ciencia e Investigación Agraria 35: 181190.

Muñoz, O., S. Copaja, H. Speisky, R. Peña, and G. Montenegro. 2007. Contenido de flavonoides y compuestos fenólicos de mieles chilenas e índice antioxidante. Química Nova 30: 848-851.

Sant'Ana, L.D., A.B. Buarque F., M.C. Affonso. L., R.L. Louro B., and R.N. Castro. 2014. Correlation of total phenolic and flavonoid contents of Brazilian honeys with colour and antioxidant capacity. International Journal of Food Properties 17:65-76.

Sawyer, R. 1981. Pollen Identification for Beekeepers. University College. Cardiff, Wales, UK. 112 pp. 